REGIONALIZATION AND HARMONIZATION IN TVET 
PROCEEDINGS OF THE $4^{\text {TH }}$ UPI INTERNATIONAL CONFERENCE ON TECHNICAL AND VOCATIONAL EDUCATION AND TRAINING (TVET 2016), 15-16 NOVEMBER 2016, BANDUNG, INDONESIA

\section{Regionalization and Harmonization in TVET}

Editors

Ade Gafar Abdullah \& Tutin Aryanti

Universitas Pendidikan Indonesia, Bandung, Indonesia

Agus Setiawan

Universitas Pendidikan Indonesia, Bandung, Indonesia

Maizam Binti Alias

University Tun Hussein Onn, Johor, Malaysia

\section{Routledge \\ Taylor \& Francis Group}

LONDON AND NEW YORK 
Cover illustrations:

\section{Villa Isola.}

Villa Isola is one of Bandung's colonial heritage, which was designed by C. Wolff Schoemaker (1882-1949), commissioned by D.W. Berretty (1890-1934) in 1932. It is located in Universitas Pendidikan Indonesia Bumi Siliwangi campus and has served as its landmark. The building, designed using Nieuwe Bouwen style, was originally Berretty's residence but handed over to the university as the university was established as Teachers Education College in 1954.

Photographer: Agus Juhana

Routledge is an imprint of the Taylor \& Francis Group, an informa business

(C) 2017 Taylor \& Francis Group, London, UK

Typeset by V Publishing Solutions Pvt Ltd., Chennai, India

Printed and bound in Great Britain by CPI Group (UK) Ltd, Croydon, CR0 4 YY

All rights reserved. No part of this publication or the information contained herein may be reproduced, stored in a retrieval system, or transmitted in any form or by any means, electronic, mechanical, by photocopying, recording or otherwise, without written prior permission from the publisher.

Although all care is taken to ensure integrity and the quality of this publication and the information herein, no responsibility is assumed by the publishers nor the author for any damage to the property or persons as a result of operation or use of this publication and/or the information contained herein.

Published by: CRC Press/Balkema

Schipholweg 107C, 2316 XC Leiden, The Netherlands

e-mail: Pub.NL@taylorandfrancis.com

www.crcpress.com - www.taylorandfrancis.com

ISBN: 978-1-138-05419-6 (Hbk)

ISBN: 978-1-315-16656-8 (eBook) 


\section{Table of contents}

Preface

Acknowledgments $\quad$ xiii

Organizing committees $\quad$ xV

Standardization in regionalization and harmonization

Integrated competency-based assessment and certification in vocational high school in Indonesia

B. Santosa \& M. Muchlas

G. Tjahjono \& T. Setiawaty

The Indonesian national competency standards in technical and vocational education and training: An evaluation of policy implementation in Indonesia

M. Sayuti

An analysis of determinants and obstacles of vocational high school students' internships

R.I. Rokhmawati \& S. A. Wicaksono

\section{Skill and personal development}

Life-skill education model for empowering elderly people

A. Hufad, J.R. Pramudia \& M.I. Hilmi

Developing national core standard for TVET personnel in the Malaysian education system

A. Ismail, R. Hassan, M. M. Mohamad \& D.I. Rosli

Transferable skills of engineering students and lecturers at universities in Indonesia and Malaysia

A. Setiawan, M. Bukit, I. Kuntadi, J.M. Yunos, K. M. Salleh, L.C. Sern,

N.L. Sulaiman \& M.F. Mohamad

Work-oriented vocational learning

A. Ana, A. G. Abdullah, I. Widiaty, S. Subekti \& Saripudin

Skills development and employment within the TVET context in Timor Leste

G.S. Ximenes \& M.L. Soares

Developing a culture-based teacher education and training program model: Improving teachers' content and pedagogical knowledge

I.P. Soko, A. Setiawan \& A. Widodo

English language training in the TVET context in Timor-Leste

J.P. Martins

Malaysian teachers' competency in technical vocational education and training: A review

K. Ismail, Z.M. Nopiah, M.S. Rasul \& P.C. Leong

Needs identification in strengthening the skills of construction workers with the national working competency standards 
The Human Resource Management (HRM) professional competency standard in Indonesia:

How should HRM lecturers address it?

M.C. Sondari, H. Koesmahendra \& W.O. Zusnita

\section{Social and cultural issues}

Profile of learning that develops mathematics creativity of junior high school students

Alimuddin \& S. Asyari

Entrepreneurial intentions: A review of self efficacy of tourism vocational school students

A. Ana, Y. Rostika, Y. Rahmawati \& R. Hurriyati

Photovoice as promotion media to grow empathy leads to a non-discriminating treatment against people living with HIV/AIDS

A. Demartoto, R. B. Soemanto \& S. Zunariyah

Finding Sudalarang as an architecture vocational village

D.P. Mulyana, L. Widaningsih \& T. Megayanti

Perception of vocational high school students on the transformation of local wisdom value

E.E. Nikmawati, I. Widiaty, R. Hurriyati \& Y. Achdiani

Developing content of curriculum based on local wisdom in a vocational high school

I. Widiaty, I. Kuntadi, Y. Achdiani \& A. Ana

Developing training and vocational education for achieving gender equality

I.D. A. Nurhaeni, Y. Kurniawan \& Supartiningsih

The development of Indonesian textbooks-based collaborative learning to strengthen character education: A case study on vocational education in Sebelas Maret University

K. Saddhono \& P.Z. Diana

English as a second language for an international nursery student in United Kingdom Mukhaiyar, S. Utari \& R. Mukhaiyar

Confirmatory factor analysis of trans-adapted generalized trust belief scale in Bahasa Indonesia on poor adolescents in vocational high schools

N. Astiyanti, D. Harding \& E. Fitriana

Traditional game to educate togetherness by Anak Bawang Community

S. H. Pujihartati \& M. Wijaya

The participation of surakarta children forum in annual community consultations on development planning as democratic education media

S. Yuliani, R. Humsona \& R. H. Haryanti

Towards collaborative governance for conflict resolution of diverse interest groups

Sudarmo

\section{Teaching innovations in TVET}

Vocational students entrepreneurial personality analysis through application of self-designed project learning model

A. Hamdani, A. Djohar, B. Darmawan \& A. Hadian

Teaching factory development model to improve the productive capability of vocational education students

A. Sutopo, A. Rahman \& D. Mulyana

The socio-cultural learning in an Indonesian Polytechnic

A. Abduh \& R. Rosmaladewi

The development of an android-based English vocabulary introduction education game for early childhood

A.B. Utomo, G.D. Robbani \& S. Nurmasitah 
Development of graphic design learning model based on multimedia

Learning computational thinking through introductory programming at the engineering faculty of the State University of Surabaya

E. Hariadi

Design and development of animation-based multimedia to illustrate corrosion and

coating processes for vocational learners

E. Permana \& Y. Sukrawan

A comparative study of learning interest and creativity between male and female students Farihah \& B. Sanjaya

Peer tutoring as a way of improving students' achievement in the digital drawing subject

H. Juniati, T. Aryanti \& T. Megayanti

The effectiveness of web-based interactive blended learning model in programming language courses

H. Effendi \& Y. Hendriyani

The influence of the vocational learning process on the acquisition of employability skills attributes mediated by performance assessment

I. M. Suarta

Integration model of employability skills in vocational education to support competitive industry

I. Hanafi, M. Ma'sum \& R. Febriana

Vocational learning tools based on scientific learning

J. Kustija \& D. Fauziah

Learning building construction based on local wisdom in Sundanese traditional

buildings with sets vision and mock-up media

J. Maknun, I. Surasetja, T. Busono \& R. Mardiana

Instructional model to improve problem solving, creativity and team working skills

for TVET student teachers

M. Samani, Suparji \& R. Rahmadian

The learning model development of higher order thinking on electronics system subject

M. Anwar, N. Jalinus \& Pardjono

The implementation of multimedia animation to improve the mastery of material about crystal defects in engineering courses

M. Komaro, A. Djohar, A. Setiawan, B. Hasan \& A. Wibi

Students' competence with reasoning ability using problem-based instruction modules in 'building materials science'

N.F.D.B. Pakpahan

Attention cueing in developing Simplified Data Encryption Standard (SDES) simulation

P.W. Yunanto, A. Diamah \& Soeprijanto

The effectiveness of Student Team Achievement Division (STAD) on academic achievement and social behavior

R. Febriana, Z. Akbara \& Mahdiyah

Self-directed learning skills in a study program of agroindustry education technology

using portfolio-based advice

S. Handayani, M.N. Handayani \& D. Cakrawati

Upgrading student creativity in computing subjects by synectics application

S.C. Wibawa, R. Harimurti, B. Sujatmiko, F.I. Sari \& S. Dwiyanti 
Developing project-based CAD teaching-learning module to improve the vocational competence of mechanical engineering students

T. Wiyanto

The development of critical thinking ability through the implementation of a Technological

Pedagogical Content Knowledge (TPCK) framework in vocational secondary schools

T. Busono, E. Krisnanto, T. Aryanti \& J. Maknun

Interactive multimedia-based learning to improve students' creative thinking skills

Y. Irawati, L. Nurlaela \& M. Wahini

Innovations in engineering and education

Sprint device development using an infrared laser with a computer interface system

A. Rusdiana

Network planning software development for wireless communication system subject

learning media

A.B. Pantjawati, E.A. Juanda, B. Mulyanti \& M. Mutasimbillah

Model of instructional thematic game to improve understanding of children with intellectual deficiencies using voice kinect sensor

D. Kuswardhana \& S. Hasegawa

Performance improvement of a domestic refrigerator using parallel expansion device

267

D. Supriawan, E.T. Berman, M. M. Al Gifari \& M. Mutaufiq

Internship program in higher vocational education: Students' performance evaluation

D. Zakaria, A.G. Abdullah, M. Somantri \& A.A. Danuwijaya

271

Effect of installation of a T-junction on the performance of an air-conditioning system

E.T. Berman, A. Setiawan, S. Hasan \& M. Mutaufiq

Analysis of computer science curriculum development to improve competency of graduates for global workforces market

F. Purwani \& Y. Desnelita

The implementation of radio frequency identification as a learning tool to increase

a student's creativity

G.R. Dantes, K. Sudarma, G. Nurhayata \& N. Dantes

of the e-learning system

G.R. Dantes, N.K. Suarni, P.H. Suputra, N.K.A. Suwastini \& I.N. Jampel

Performance investigation of an air-cooled chiller system using pure

hydrocarbons as refrigerant

K. Sumardi, E.T. Berman \& M. Mutaufiq

Evaluation of the learning program in the building construction materials course

in vocational education

K. Wijaya

Long-term power load forecasting in the Java-Bali electricity system using neural network backpropagation

L. Anifah, S.I. Haryudo \& R. Ardian

Vocational education with multi-competency based on community needs

Mukhidin, S. Prihartiningsih \& A. Mustikawanto

"Memetri Kali" as transformative learning model for sociology students to care

about environmental issues

S. Zunariyah \& A. Ramdhon 
Implementation of the learning model of Team-Assisted Individualization (TAI) to improve student activity and student learning outcomes

S. Siregar

Management of cooperation and partnership in vocational high schools

for improving graduate competencies

T. Setiawaty \& G. Tjahjono

Technical and vocational education and training in the secondary stage: A case study V.A. Shamsudeen

Multimedia learning to increase student achievement in metal corrosion and coating subject material

Y. Sukrawan, R.A. Hamdani \& M. Komaro

Author index 


\section{Preface}

The $4^{\text {th }}$ UPI International Conference on Technical and Vocational Education and Training was held in Bandung (Indonesia) on 15-16 November 2016. The conference is a biannual event, which has been conducted by the Universitas Pendidikan Indonesia's TVET Research Center and the Faculty of Technology and Vocational Education. Like the three previous conferences, this conference received enthusiastic response from scholars and practitioners of TVET around the world. Participants from Malaysia, India, Timor Leste, and many cities in Indonesia attended this year's conference.

Exploring the theme "Regionalization and Harmonization in TVET," the conference featured Prof. Dr. Numyoot Songthanapitak, the president of the Regional Association for Vocational Teacher Education in Asia and the president of Rajamangala University of Technology Lanna, Thailand; Prof. Dr. HC. Thomas Schröder and Dr. Sven Schulte of the Technical University of Dortmund, Germany; Prof. Dr. Maizam Alias of the Universiti Tun Hussein Onn Malaysia; and Dr. Eng. Agus Setiawan of Universitas Pendidikan Indonesia as keynote speakers. Participants presented their papers, which are categorized under subthemes: Standardization in Regionalization and Harmonization, Skill and Personal Development, Social and Cultural Issues, Teaching Innovations in TVET, and Innovations in Engineering and Education.

There were approximately 200 submissions from various countries to the conference. The committee selected 70 papers to be presented in this year's conference. These papers were then selected to be published in TVET@Asia online, and a conference book, published by Taylor \& Francis and submitted for indexation in Scopus and Thomson Reuters.

Ade Gafar Abdullah, Tutin Aryanti, Agus Setiawan,

Asep Bayu Dani Nandiyanto, Ari Arifin Danuwijaya Universitas Pendidikan Indonesia, Bandung, Indonesia 


\section{Acknowledgments}

Ade Gafar Abdullah, Universitas Pendidikan Indonesia, Indonesia

Agus Setiawan, Universitas Pendidikan Indonesia, Indonesia

Ana, Universitas Pendidikan Indonesia, Indonesia

Asnul Dahar Mingat, Universiti Teknologi Malaysia, Malaysia

Budi Mulyanti, Universitas Pendidikan Indonesia, Indonesia

Dadang Kurnia, Deutsche Gesellschaft für Internationale Zusammenarbeit, Germany

Dewi Cakrawati, Universitas Pendidikan Indonesia, Indonesia

Erica Smith, Federation University, Australia

Frank Bünning, University of Magdeburg, Germany

Hiroyuki Iida, Japan Advanced Institute of Science and Technology, Japan

Ida Hamidah, Universitas Pendidikan Indonesia, Indonesia

Isma Widiaty, Universitas Pendidikan Indonesia, Indonesia

Joachim Dittrich, Internationale Tourismus-Börse, Germany

Kamin Sumardi, Universitas Pendidikan Indonesia, Indonesia

Lilia Halim, Universiti Kebangsaan Malaysia, Malaysia

Luisa Brotas, London Metropolitan University, United Kingdom

M. Syaom Barliana, Universitas Pendidikan Indonesia, Indonesia

Maizam Alias, Universiti Tun Hussein Onn Malaysia, Malaysia

Margarita Pavlova, Director, UNESCO-UNEVOC Center, Hongkong

Mohd. Sattar bin Rasul, Universiti Kebangsaan Malaysia, Malaysia

Muhammad Sukri Saud, Universiti Teknologi Malaysia, Malaysia

Nazeri bin Mohammad, Insititut Pendidikan Guru Kampus Perlis, Malaysia

Numyoot Songthanapitak, President of RAVTE, Thailand

Ramlee bin Mustapha, Universiti Pendidikan Sultan Idris, Malaysia

Sigit Dwiananto Arifwidodo, Kasetsart University, Thailand

Sirilak Hanvatananukul, Rajamangala University of Technology Thanyaburi, Thailand

Siscka Elvyanti, Universitas Pendidikan Indonesia, Indonesia

Tetsu Kubota, Hiroshima University, Japan

Thomas Schroder, Technical University of Dortmund, Germany

Tutin Aryanti, Universitas Pendidikan Indonesia, Indonesia

Usep Surahman, Universitas Pendidikan Indonesia, Indonesia 


\section{Organizing committees}

\section{ADVISORY COMMITTEE}

Assoc. Prof. Muhammad Sukri Saud Assoc. Prof. Numyoot Songthanapitak Assoc. Prof. Sirilak Hanvatananukul Assoc. Prof. Tetsu Kubota

Dr. Asnul Dahar Mingat

Dr. Joachim Dittrich

Dr. Luisa Brotas

Dr. Margarita Pavlova

Dr. Mohd. Sattar bin Rasul

Dr. Nazeri bin Mohammad

Dr. Phil. Dadang Kurnia

Dr. Sigit Dwiananto Arifwidodo

Prof. Erica Smith

Prof. Frank Bünning

Prof. Hiroyuki Iida

Prof. Lilia Halim

Prof. Maizam Alias

Prof. Ramlee bin Mustapha

Prof. Thomas Schröder

\section{CONFERENCE CHAIR}

Tutin Aryanti, Ph.D.

\section{ORGANIZING COMMITTEE}

Dewi Cakrawati, M.Si.

Dr. Ade Gafar Abdullah

Dr. Isma Widiaty

Dr. Ana

Dr. Eng. Agus Setiawan, M.Si.

Dr. Budi Mulyanti

Dr. Eng. Usep Surahman

Dr. Ida Hamidah

Dr. Kamin Sumardi

Dr. Siscka Elvyanti

Prof. Dr. M. Syaom Barliana

Nia Amelia, S.Pd.

Diky Zakaria, S.Pd.

Agus Juhana, S.Pd. 
Standardization in regionalization and harmonization 


\title{
Integrated competency-based assessment and certification in vocational high school in Indonesia
}

\author{
B. Santosa \& M. Muchlas \\ Ahmad Dahlan University, Yogyakarta, Indonesia
}

\begin{abstract}
The objective of this research is to find a model of Integrated Competency-Based Assessment (ICBA) and certification that is appropriate for implementation in Vocational High School (VHS). The model is a test of competence that is combined with a learning and assessment process. This study used research and development established by Gall et al. The results of this research found that the model of ICBA and certification was feasible for implementation in VHS. The model was created through the aspects of developing competency standards and competency-based training development in work practices. The competency standard was developed through setting standards of competence and suitability needed for the job. The development of vocational learning is achieved through the professionalism of the teacher, the development of learning resources and learning models, evaluation models, and the reporting of learning outcomes in the form of a skills passport. Developing a competency-based assessment was done in the context of the examination system by working on real jobs.
\end{abstract}

\section{INTRODUCTION}

Vocational High School (VHS) has the purpose of preparing students for work and/or continuing their studies. The vocational education system should be able to prepare graduates to have competence in accordance with industry standards, both nationally and internationally. VHSs in Indonesia have implemented the concept of a dual system of education. Education and training can be done in schools and in industry, based on program link and match. Students learn the basic theory and practice in vocational school, then study and work at the company as an apprentice. This dual system is based on the view that vocational education will be efficient if the environment in which students are trained is a replica of the environment where they will be working (Prosser \& Allen, 1925).

This study sought to establish competency test models that combine the learning process in schools and learning in industry (industrial working practices) with the assessment process. The curriculum was developed according to the needs of industry and standards in the workplace. Learning at school or in the workplace was adapted to the results of curriculum development conducted by the school and industry. The integrated competency test model is a model that combines aspects of the competency test curriculum development, learning at school, and learning in industry through industry working practices with the assessment process/competency test in order to establish the knowledge and skills of students according to the test of competency standards that apply in the workplace.

\subsection{Curriculum development}

While Finch and Crunkilton (1999, p. 11) state that the curriculum is defined as the number of learning activities and experiences which students are expected to have; it is like the direction of the school. Scott and Sarkees-Wircenski (2004, p. 396) state that the principle of a vocational education curriculum is derived from the needs of the world of work. Given the three definitions above, it can be concluded that the curriculum is the teaching and learning process that aims to improve the knowledge, skills, and experience of students in formal educational institutions, where the curriculum comes from the needs of the working world.

Cumming and Wyatt-Smith $(2009$, p. 1) state that assessment (and its interface with curriculum, teaching, and learning) has always been a significant component of classroom practice. Their opinion suggests a scoring system linking the curriculum with teaching and learning. Further, that in implementing the curriculum development, the system of learning, teaching and assessment should be considered.

\subsection{Competency-Based Training (CBT)}

According to Palomba and Banta (1993, p. 30), competence is a knowledge, skill, ability, quality of 
personal experience, or other characteristic that is applicable to learning and success in school or in work.

According to Gonczi (1998, p. 222):

To reform vocational education and training within a framework of national competency standards cannot succeed without a change in thinking about assessment methods and the conceptualization of competence requires a holistic approach, which integrates knowledge and skills with realistic workplace practices.

This statement implies that the method of assessment should be modified according to the standards of competence that have been determined. In concept, competence requires an integral approach between knowledge and the skills to practice in a real workplace.

\subsection{Competency-Based Assessment (CBA)}

Gonczi (1998, p. 38) states that CBT is characterized by the relationship between education/training and a Competency-Based Assessment (CBA) system. Competence standards are a major benchmark in the implementation of assessment/competency-based testing. On the other hand, CBA can be done while the trainees/students work in the workplace. Someone who is doing industry practice (on-the-job training) may be tested when they have been able to do the job.

Assessment is a process that involves the collection of evidence that is the basis for determining the progress or achievement of a student or trainee in relation to appropriatelearning objectives (Hawke\& Oliver, 1998, p. 244). As Miller (2008, p. 2) states, assessment is a broader term than test and the general process that includes gathering, synthesizing and interpreting data involves informal and formal data. Furthermore, Finch and Crunkilton (1999, p. 271) stated that the assessment is the determination of the benefit or value derived from the curriculum (or a part of the curriculum). Assessment is the process of gathering, synthesizing and interpreting data about the learning process as the implementation of the curriculum.

\subsection{On-the-Job Training (OJT)}

Van der Klink and Streumer (2006, p. 369) state that On-the-Job Training (OJT) is intended to: (a) increase the flexibility of learning programs in the workplace, (b) facilitate transfer of classbased learning, because the workplace and place of learning is identical, and (c) change the nature of work to provide more possibilities for integration between learning and work. Van der Klink and Streumer are of the opinion that on-the-job training can be described as a workplace learning program whose aim is to get learning in the classroom and in the workplace closer together so that the existing competence in the world of work can be acquired by the learners.

The importance of OJT to vocational education is that it can add work experience. Thompson (1973, p. 240) states that OJT is very important for high-school students who want to know how it feels to work in certain jobs. This means that OJT can improve skills when students work. So, to get the skills to apply in the workplace, students must perform on-the-job training in industry.

\section{RESEARCH METHODS}

\subsection{Model development}

This study aims to develop a test model of competence in VHS and is intended to generate a product in the form of a test model of CBA. Thus, in this study there is a product development activity, and therefore this research includes a form of Research and Development (R\&D). In this case, the researchers chose an $R \& D$ research model developed by Gall et al. (2007, pp. 589-594), modified by Sukmadinata (2011, pp. 184-190).

The steps of this R\&D can be described as follows. The first step is a preliminary study that provides: (a) a study of the literature on the aspects studied, whether derived from the theory, research, or field studies related to competency testing, and (b) the drafting of a competency test product based on the literature and expert judgment and conducted through Focus Group Discussion (FGD) with experts/academics and practitioners in educational institutions and industry/associations. The second step is the development of products, which consists of (a) a limited product trial conducted in two VHSs, and (b) expanded product trials conducted in four VHSs. The third step consists of end-product testing and the dissemination of the associated results.

\section{RESULTS AND DISCUSSION}

\subsection{Result}

This study was conducted in two stages: the first stage is done by taking a vocational course selected with a qualitative approach; the second stage was testing of the model developed on the basis of the research results.

\subsubsection{Practice teaching and learning activities in $V H S$}

Some of the findings of practices at the VHS were: (a) the teacher is not required to have a certificate of competency or to become an independent assessor; (b) students learn in working groups of four 
students, each group having a different job; (c) students wrote a report on the practice and at the end of the meeting there was an evaluation; (d) not all of the materials tested practices; (e) students who failed remedial tests; (f) the result of the practices of the students takes the form of report cards.

\subsubsection{Industrial Work Practice (IWP) in the workshop}

Observations of the times that the students carry out learning in the workplace in the form of working industrial practices revealed that: (a) students are required to follow a program in the practice of industrial work; (b) students are given the freedom to select a location as desired; (c) students work according to the type of work in the workshop with the guidance of a mechanic who was appointed during the performance of the IWP; (d) the students record all of the types of work that have been done in a daily journal; (e) IWP does not provide practice exams for students; (f) students who have qualified will get an IWP certificate signed jointly by the school principal and the leadership of the industry/workshops.

\subsubsection{Vocational Practice Exam (VPE)}

External assessors of the industry make no judgment directly on the competencies being tested, due to the limited number of industry assessors. The number of external assessors in Yogyakarta VHS for the implementation of this Vocational Practice Exam (VPE) numbers just two people who cannot be fully present for the VPE. Administratively, the student assessment sheet is signed by two assessors, namely external assessors from industry and internal assessors/teachers, but technically the assessment is carried out by the internal assessor/teacher, then external assessors sign the assessment sheet that has been filled in by the internal assessors. At just two people, the number of external assessors is not sufficient compared to the number of VPE tests undertaken.

\subsection{Discussion}

The opinions of experts regarding these CBA models are analyzed in the discussion, based on the study of the theory and the data obtained. This part mainly consists of two parts. First, it discusses experts' opinions, including existing theories and research results on CBA models. Second, it discusses the final product of CBA models of this study.

\subsubsection{Competency standards development}

Standard Kompetensi Kerja Nasional Indonesia (SKKNI) is used as a guide in developing competency standards in vocational training because the purpose of vocational education is to prepare students for work. Norton (2008, pp. 17-18) suggests that in a standard task analysis of needs, work begins and ends with the development of competency profiles. Norton's opinion suggests that, in the development of competency standards, there is a need to analyze the needs of the work, which is none other than already stated in SKKNI, and developed into a competence standard.

Another opinion, expressed by Kelly (2000, pp. 14-15), states that in formulating basic standards in vocational education, concepts and basic operations and aspects of humanity, ethics and society need to be developed. Statements by Norton and Moser (2008) and Kelly (2000) confirmed that there needs to be a blend between the curriculum and SKKNI in developing competency standards in VHS.

\subsubsection{Curriculum development}

Putting a team of experts who are claimed to be experts on curriculum development and subjects in the curriculum is necessary for curriculum development, in addition to considering business and industry elements. Thus, this team ideally consists of: (a) administrators - academics in the field of vocational education; (b) instructional staff - an instructor in engineering fields; (c) support personnel - the developer of the curriculum/program; (d) advisory personnel - a committee of experts/professional associations. The opinion of Norton and Moser (2008) suggests that the members who should be involved so that the curriculum can be developed effectively and efficiently include engineering education experts, curriculum developers, and practitioners.

Rauner (2009, p. 1582) states that in the development of a vocational education curriculum, the occupational form of work is the main point of reference for the development of curricula. Rauner's opinion suggests that in developing the vocational education curriculum, forms of work related to the position/task become a reference in the development of the curriculum. Another opinion that supports consideration of the needs of students and social conditions was expressed by Prosser in Scott and Sarkees-Wircenski (2004, p. 390-391), which states that vocational education as an educational institution must expand opportunities for students to study or work as needed.

\subsubsection{Competency-based training development}

Input from a team of experts who claim that the module as a source of learning needs to be enriched with other learning resources to give students flexibility, in accordance with the opinion of Norton and Moser (2008, pp. D1-D2), states that learning should be able to provide a program for individual development, and the learning process can take place in the workplace. The learning model needs to be developed in the direction of cooperative learning and in accordance with the demands of the curriculum, in line with the expert opinion of 
Dewey in Clark and Winch (2007, pp. 126-127), who states that vocational education has characteristics that include, firstly, a curriculum that demonstrates relevance to the vocational needs and, secondly, the knowledge needed to provide a better approach to the learning process.

\subsubsection{Development of Industrial Work Practice (IWP)}

The expert judgment which states that there needs to be standardization of competence in the IWP program, along with the imposition of performance criteria in the workshop where students practice industrial work, was supported by the opinion of van der Klink and Streumer (2006, p. 375), who suggest that learning in the workplace be based on training design details, such as contained in instructional design theory. The purpose of training is determined according to analysis tasks in the workplace, and learning materials should be developed in accordance with the conditions in the workplace. The standardization of competences, along with their performance criteria, should contribute to the skills passport of vocational students following an IWP program.

\subsubsection{Development of an Integrated Competency- Based Assessment (ICBA)}

According to expert judgment, the development of an ICBA and the use of a first-party professional certification agency (Lembaga Sertifikasi Profesi Pihak-1 (LSPP-1)) at a VHS should be supported by strong policies and regulations. The ICBA should be carried out by a professional certification institution recognized by the certification body of the relevant profession in order to obtain the recognition of an independent agency. Under the guidelines of the National Professional Certification Board (Badan Nasional Sertifikasi Profesi (BNSP)), education and training institutions can seek the presence of LSPP1. Students are tested by LSPP-1, which has received accreditation from BNSP. ICBAs, in the form of collecting evidence of competence, were conducted by LSPP-1. Students who have demonstrated evidence of competence have been declared competent and certified by LSPP-1. Students who have not been certified competent to work practice in industry, and together with students who want to gain competency, are tested by LSPP-1 using patterns established through work/simulation. Students who have satisfied all competency packages will receive a technician certificate and those who have got the certificate of compliance that they meet a competency have mastered the skill contained in the passport.

\subsubsection{Final development of ICBA model}

Verification is done by LSPP-1 on the results of the ICBAs completed by students during IWP. If the results are in accordance with the standards of com- petency that have been listed in the skills passport, then LSPP-1 issues a certificate of competence. If the results are not in accordance with the criteria, then the student does not receive a certificate of competence. Students who have not been declared competent by the industry when implementing industrial working practices, are given the opportunity to follow up with a competency test in a work simulation conducted by LSPP-1 at an assessment center in the VHS. The material in the ICBA covers competency clusters that have been listed in the skills passport in accordance with the student's choice. The revised ICBA end models from the final product assessment by the experts can be seen in Figures 1 and 2 (see Appendix).

\section{CONCLUSION}

Based on the results of data analysis and discussion, the results of this study can be summarized as follows.

1. The model for a competency test was conducted at VHSs in the form of the VPE, which is an integral part of the examination conducted in the context of the National Education Standards.

2. Barriers to ICBA implementation in VHSs are: (a) vocational training has yet to have independent professional certification agencies; (b) the VPE that has been used to date is based on a simulation of real work patterns; (c) the certificates of competency issued by VHSs have not received recognition from an independent professional certification agency.

3. The ICBA model we have developed for VHSs includes: (a) competency standards developed according to a blend of SKKNI for the automotive industry with Standar Kompetensi Lulusan (SKL); (b) synchronization with the syllabus requirements of existing jobs in industry, reviewed regularly every year; (c) components of vocational learning such as teachers becoming independent assessors, students gaining material soft skills through the inculcation of a Kaizen culture, progress reports in the form of skills passports, and VHSs having TUK, and becoming independent professional certification agencies; (d) students carrying out IWP with a focus on clusters of competence, with competency tests conducted on the basis of a real job in the industry.

4. The ICBA model that is feasible in VHSs is a competency test that combines the learning process with a process of assessment/examination conducted when students carry out industrial work practice and based on a pattern of student work on real jobs. 


\section{REFERENCES}

Clark, L. \& Winch, C. (2007). Vocational education: International approaches, developments and systems. Abingdon, UK: Routledge.

Cumming, J.J. \& Wyatt-Smith, C. (2009). Framing assessment today for the future: issues and challenges. In Wyatt-Smith, C. \& Cumming, J.J. (Eds.), Educational assessment in the 21st century: Connecting theory and practice. Dordrecht, The Netherlands: Springer.

Finch, C.R. \& Crunkilton, J.R. (1999). Curriculum development in vocational and technical education: Planning, content, and implementation (5th ed.). Needham Heights, MA: Allyn \& Bacon.

Gall, M.D., Gall, J.P. \& Borg, W.R. (2007). Educational research: An introduction (8th ed.). Boston, MA: Pearson Education.

Gonczi, A. (Ed.) (1998). Developing a competent workforce: Adult learning strategies for vocational educators and trainers. Adelaide, Australia: National Centre for Vocational Education Research (NCVER).

Hawke, G. \& Oliver, L. (1998). Assessment in modern vocational education. In Gonczi, A. (Ed.), Developing a competent workforce: Adult learning strategies for vocational educators and trainers. Adelaide, Australia: NCVER.

Kelly, M.G. (2000). National educational technology standards for students: Connecting curriculum and technology. Eugene, OR: International Society for Technology in Education.
Miller, P.W. (2008). Measurement and teaching. Munster, IN: Patrick W Miller and Associates.

Norton, R.E. \& Moser, J.R. (2008). DACUM (Developing a curriculum) handbook (3rd ed.). Columbus, OH: Center on Education and Training for Employment.

Palomba, A.C. \& Banta, W.T. (2001). Assessing student competence in accredited disciplines: Pioneering approaches to assessment in higher education. Sterling, VA: Stylus Publishing.

Prosser, C.A. \& Allen, C.R. (1925). Vocational education in a democracy. New York, NY: Century.

Rauner, F. (2009). TVET curriculum development and delivery. In Maclean, R. \& Wilson, D. (Eds.), International handbook of education for the changing world of work: Bridging academic and vocational learning. Dordrecht, The Netherlands: Springer.

Scott, J.L. \& Sarkees-Wircenski, M. (2004). Overview of career and technical education (3rd ed.). Homewood, IL: American Technical Publishers.

Sukmadinata, N.S. (2012). Metode penelitian pendidikan. Bandung, Indonesia: PT Remaja Rosdakarya.

Thompson, J.F. (1973). Foundations of vocational education: Social and philosophical concepts. Englewood Cliffs, NJ: Prentice-Hall.

van der Klink, M.R. \& Streumer, J.N. (2006). The effectiveness of OJT in the context of HRD. In Streumer, J.N. (Ed.), Work-related learning (pp. 369-392). Dordrecht, The Netherlands: Springer. appendix 


\section{APPENDIX}

\section{DEVELOPMENT OF COMPETENCE} STANDARD :

1. Develop by Indonesian Competence Standard, standard of education, and industry needs.

2. Competence standard breakdown in criteria of working performance
DEVELOPMENT OF CURRICULUM:

1. Curriculum synchronization with industry do every year.

2. Legalization and signature by VHS Principal, Industry Association, School Committee, and Education Department Office

\section{LEARNING PRACTICE IN VHS :}

1. Teacher must have a competence certificate and be an independent assessor.

2. Learninng model in competency-based training (CBT)

3. Skills passport includes basic skills (VHS) and working skills (industry)

4. Student gets a soft skills

5. VHS has assessment centre

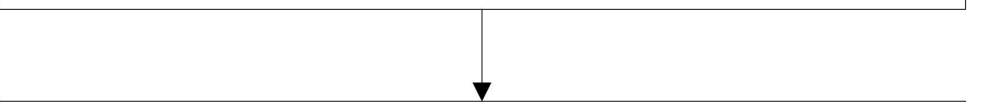

WORKING PRACTICE IN INDUSTRY:

1. Student chooses industry has memorandum of understanding with VHS

2. Before working practice in industry, student must be observer in the industry and choose the focus competencies and must be agreed by industry.

3. Assessment must be implemented in real job.

4. Supervisor assesses student.

5. Material of CBA is cluster competencies referring to industry job.

6. Result of CBA must be recorded in the skills passport.

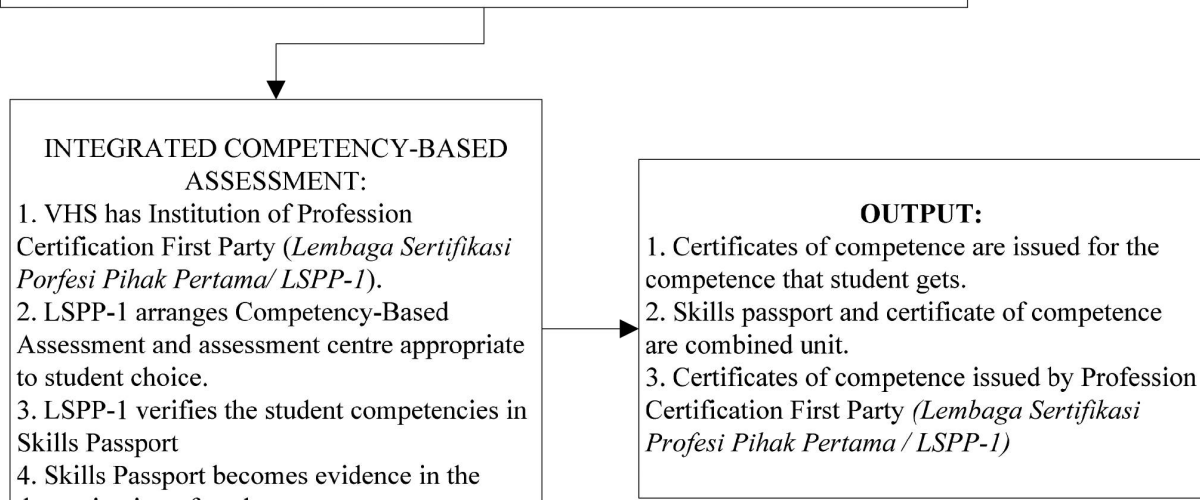

Figure 1. ICBA flow chart. 


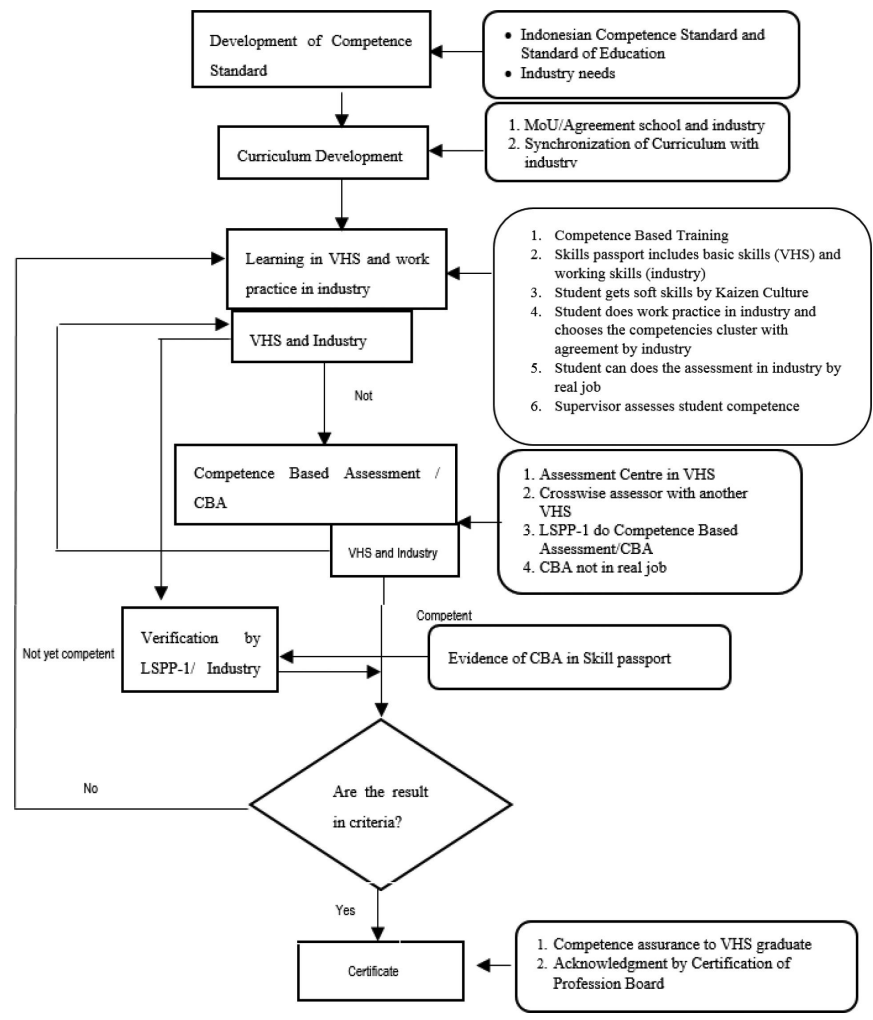

Figure 2. ICBA model. 